\title{
THE EFFECT OF SUCTION DRAINS AFTER TOTAL HIP REPLACEMENT
}

\author{
K. M. WilletT, C. D. Simmonst, G. BENTLEY
}

\author{
From The Institute of Orthopaedics and the Royal National Orthopaedic Hospital, London
}

\begin{abstract}
A prospective study of 120 consecutive total hip replacements showed that deep suction drains produced maximal drainage volumes in the first 24 hours. Their continued presence resulted in minimal further drainage, did not reduce the likelihood of haematoma formation and led in some cases to the spread of skin organisms into the wound.
\end{abstract}

Deep suction drainage of wounds following total hip replacement has become an established routine in orthopaedic practice, with the aim of preventing wound haematomas and thereby reducing infection. Some previous workers have demonstrated that closed suction drainage is effective and provides a less complicated postoperative course (Waugh and Stinchfield 1961). Others, however, have produced evidence of the migration of skin micro-organisms along drains to deep surgical wounds (Cerise, Pierce and Diamond 1970; Nora, Vanecko and Bransfield 1972). Magee et al. (1976) showed that in contaminated experimental wounds the presence of drains enhanced infection by damaging host tissue resistance.

In an attempt to clarify the role of closed deep suction drains following total hip replacement, we decided to study a series of cases prospectively.

\section{PATIENTS AND METHODS}

One hundred and twenty patients who had undergone total hip replacement with a Charnley or Stanmore cemented prosthesis were studied. They were divided into three groups A, B and C depending on the time of removal of their "Redivac" suction drains at 24,48 or 72 hours after operation. A primary arthroplasty was performed in 106 cases and a revision procedure in 14 . The total volume of fluid drained at $12,24,48$ and 72

K. M. Willett, FRCS, Orthopaedic Registrar Department of Orthopaedics, Charing Cross Hospital, London W6
8RF, England.

†C. D. Simmons, MB BS, deceased

G. Bentley, ChM, FRCS, Professor of Orthopaedic Surgery

Institute of Orthopaedics, Royal National Orthopaedic Hospital, Brockley Hill, Stanmore, Middlesex HA7 4LP, England.

Correspondence should be sent to $\mathrm{Mr} \mathrm{K}$. M. Willett.

(C) 1988 British Editorial Society of Bone and Joint Surgery $0301-620 \mathrm{X} / 88 / 4138 \$ 2.00$

J Bone Joint Surg [Br] 1988;70-B:607-10. hours after operation was recorded in each case. The antibiotic regime was comparable in all cases: $1 \mathrm{G}$ of Amoxycillin and $1 \mathrm{G}$ of Flucloxacillin two hours before operation and 0-5G of both antibiotics at six and 12 hours after operation.

Standard proprietary polyvinyl chloride (PVC) suction drains with an external diameter of $3 \mathrm{~mm}$ were used. These were attached by a closed system to prevacuumed glass bottles. Bottle changes were only made if the bottle became full or if the suction pressure fell below the recommended level $(50 \mathrm{~mm} \mathrm{Hg})$. The suction tubing was clamped during bottle changes.

All the observations were made by the authors and they themselves removed all the drains. The drain tubing was removed at the bedside using a sterile technique. The exit site was exposed and a wet swab taken from the surrounding skin for culture. The drain was then extracted in one movement without contamination. The fluid content of the proximal portion of the drain (termed the deep aspirate) was cultured. A swab was taken from the surface of the proximal $4 \mathrm{~cm}$ of drain which had been in contact with the subcutaneous drain track; this also was cultured. Finally a fourth culture was taken with a sterile inoculating wire loop introduced (using a sterile funnel) into the drain track and scraped along the walls.

All culture samples were immediately plated out at the bedside onto aerobic and anaerobic blood agar, and cystine lactose electrolyte deficient media. They were then incubated for 48 to 72 hours. Any plate which showed a positive culture at this time for any site other than skin was then subjected to further identification and testing, and compared to the organism grown from the skin swab of that patient. The tests used to compare organisms were the antibiotic sensitivities screen and the Analytical Profile Index (API) system.

In the postoperative period all patients were observed for the presence of wound infection and the development of haematomas. A haematoma was graded "minor" if it delayed discharge from hospital but subsided spontaneously, or "major" if it was larger and required aspiration. 
Table I. Results of drainage

\begin{tabular}{lllllll}
\hline & $\begin{array}{l}\mathbf{1 2} \text { hours } \\
\mathrm{n}=120\end{array}$ & $\begin{array}{l}\mathbf{2 4} \text { hours } \\
\mathrm{n}=120\end{array}$ & $\begin{array}{l}\mathbf{4 8} \text { hours } \\
\mathrm{n}=87\end{array}$ & $\begin{array}{l}\mathbf{7 2} \text { hours } \\
\mathrm{n}=28\end{array}$ & $\begin{array}{l}\text { 12-hour loss } \\
\text { (per cent) } \\
\mathrm{n}=120\end{array}$ & $\begin{array}{l}\text { 24-hour loss } \\
\text { (per cent) } \\
\mathrm{n}=87\end{array}$ \\
\hline Mean volume in $m l$ & 372 & 445 & 509 & 604 & 79 & 91 \\
Range in $m l$ & 50 to 1090 & 60 to 1265 & 70 to 2150 & 295 to 2425 & 34 to 100 & 58 to 100
\end{tabular}

Table II. Mean drainage characteristics

\begin{tabular}{lllll}
\hline $\begin{array}{l}\text { Postoperative } \\
\text { period }\end{array}$ & $\begin{array}{l}\text { Number of } \\
\text { cases }\end{array}$ & $\begin{array}{l}\text { Mean volume } \\
\text { in } \boldsymbol{m l}\end{array}$ & $\begin{array}{l}\text { Fraction of } \\
\text { total loss } \\
\text { (per cent) }\end{array}$ & $\begin{array}{l}\text { Cases with } \\
\text { no drainage }\end{array}$ \\
\hline $\mathbf{0}$ to 24 hours & 120 & 445 & 90.9 & 0 \\
24 to 48 hours & 87 & 44.2 & 8.5 & 16 \\
$\mathbf{4 8}$ to 72 hours & 28 & 23 & 3.8 & 14 \\
\hline
\end{tabular}

\section{RESULTS}

\section{Drainage}

The results are given in Tables I and II. These may be summarised as follows:

All 120 cases. Within the first 12 hours from operation $79 \%$ (range 31 to $100 \%$ ) of the total drainage occurred. The mean loss was $372 \mathrm{ml}$ (range 40 to $1090 \mathrm{ml}$ ). Within the first 24 hours $91 \%$ (range 58 to $100 \%$ ) of the total drainage occurred. The mean loss was $445 \mathrm{ml}$ (range 50 to $1265 \mathrm{ml}$ ). Between 24 and 48 hours the mean loss in 87 cases was $44 \mathrm{ml}$ (maximum $300 \mathrm{ml}$ ) and in 16 of these it was zero. Between 48 and 72 hours the mean loss in 28 cases was $23 \mathrm{ml}$ (maximum $275 \mathrm{ml}$ ) and in 14 of these it was zero.

The 14 revision cases. In these, $69 \%$ of the total drainage occurred in 12 hours and $84 \%$ in 24 hours from operation. The volumes were 27 to $31 \%$ greater than in primary replacements (Table III).

\section{Complications}

Wound haematoma. Clinically a haematoma complicated recovery in 11 cases: two minor haematomas occurred in Group A (24 hour removal), seven in Group B (48 hour removal) and two in Group C (72 hour removal). Three of the seven in Group B and one of the two in Group C were major haematomas requiring aspiration. Of these nine cases, five recorded no drainage in the 24 to 48 hour postoperative period, prior to drain removal.

Wound infection. Superficial wound sepsis as indicated by redness, swelling and increased local temperature complicated five cases; one was in Group A, two in Group B and two in Group C. In no case was an organism isolated from the wound and all resolved with systemic antibiotics within ten days. In two of the five cases positive cultures were obtained from the deep aspirate at the time of drain removal. In only one case was wound sepsis found in a patient with a haematoma; this was a minor haematoma in Group B and no positive culture was obtained at drain removal.

Positive cultures. In seven of the 120 cases a positive culture was obtained from a site other than the skin. In four of these cases the organisms were coagulasenegative staphylococci obtained from the deep aspirate; in two of these the same organisms were also grown from the surface of the drain. On API testing and antibiotic sensitivities, each of the four organisms were identical to coagulase-negative staphylococci grown from the skin swab from that individual (see Table IV). In three further cases pure cultures of organisms were obtained from the deep aspirate, the drain surface, the drain track and the skin: these were aerobic spore-bearing gram-positive rods, diphtheroid bacilli and Escherichia coli respectively.

\section{DISCUSSION}

In recent decades closed suction drainage systems have replaced simple conduit drains with claimed advantages of decreased infection and haematoma rates (Cruse and Foord 1973; Morris 1973). This supports the work of Waugh and Stinchfield (1961) who, in a prospective study, compared the postoperative complications of 100 various orthopaedic procedures using closed suction drainage with a similar number of undrained matched controls. Other workers, however, (Browett et al. 1978; Reilly et al. 1986) have shown no difference in the wound complication rate or postoperative morbidity of patients undergoing meniscectomy or total knee arthroplasty with or without suction drainage. 
Table III. Results of drainage in the 14 revisions

\begin{tabular}{lllllll}
\hline & 12 hours & 24 hours & $\mathbf{4 8}$ hours & $\mathbf{7 2}$ hours & $\begin{array}{l}\text { 12-hour loss } \\
\text { (per cent) }\end{array}$ & $\begin{array}{l}\text { 24-hour loss } \\
\text { (per cent) }\end{array}$ \\
\hline Mean volume in $m l$ & 471 & 585 & 702 & 876 & 69 & 84.4 \\
Range in $m l$ & 100 to 750 & 275 to 1250 & 295 to 2150 & 295 to 2425 & 34 to 93 & 58 to 100
\end{tabular}

Table IV. Details of the positive cultures in seven patients

\begin{tabular}{|c|c|c|c|c|c|}
\hline Case & Skin & Deep aspirate & Drain surface & Drain track & $\begin{array}{l}\text { API testing } \\
\text { and antibiotic } \\
\text { sensitivity }\end{array}$ \\
\hline 1 & $\begin{array}{l}\text { Coag - ve staph. } \\
\text { ASB } \\
\text { Micrococcus }\end{array}$ & $\begin{array}{l}\text { Coag-ve staph. } \\
\text { ASB } \\
\text { Micrococcus }\end{array}$ & No group & No growth & Identical \\
\hline 2 & $\begin{array}{l}\text { Coag - ve staph. } \\
\text { Gram + ve coccus }\end{array}$ & Coag-ve staph. & No growth & No growth & Identical \\
\hline 3 & $\begin{array}{l}\text { Coag - ve staph. } \\
\text { Gram + ve coccus }\end{array}$ & Coag-ve staph. & Coag-ve staph. & No growth & Identical \\
\hline 4 & $\begin{array}{l}\text { Gram + ve rods } \\
\text { ASB } \\
\text { Staph. }\end{array}$ & ASB & ASB & ASB & Not applicable \\
\hline 5 & Diphtheroid sp. & Diphtheroid sp. & No growth & Diphtheroid sp. & Not applicable \\
\hline 6 & Gram-ve staph. & Gram-ve staph. & Gram-ve staph. & No growth & Identical \\
\hline 7 & $\begin{array}{l}\text { Coliform } \\
\text { bacilli }\end{array}$ & $\begin{array}{l}\text { Coliform } \\
\text { bacilli }\end{array}$ & $\begin{array}{l}\text { Coliform } \\
\text { bacilli }\end{array}$ & $\begin{array}{l}\text { Coliform } \\
\text { bacilli }\end{array}$ & Not applicable \\
\hline
\end{tabular}

ASB, aerobic spore-bearing Gram posititive rod.

Substantial evidence exists of the migration of skin micro-organisms into a wound along a drain. Following laboratory experiments Casey (1971) postulated the retrograde spread of organisms in static serum columns in polyethylene drainage tubing. This was demonstrated by Cerise et al. (1970) in vivo; they demonstrated the migration of skin organisms down a peritoneal drain in splenectomised rabbits, with subsequent infection of the dissection bed. Nora et al. (1972) re-affirmed this concept. More recently Raves, Slifkin and Diamond (1984) have shown convincingly that, with simple conduit drains, retrograde migration of bacteria occurs by 72 hours with relatively high frequency (75 to $90 \%$ ); with closed suction drainage the frequency is much lower $(20 \%)$. Thus it appears that there are advantages in using drains, but these advantages must be balanced against the small increased risk of retrograde spread of bacteria into the wound, a risk which appears to be reduced if closed suction drainage is employed.

From our investigation it is apparent that following total hip replacement most of the drainage along suction drains occurs in the first 12 hours; by 24 hours drainage is reduced to approximately $2 \mathrm{ml}$ per hour until the drain is removed. We also found that wound haematomas were not related to the length of time the suction drain had been in situ: removal at 24 hours was not associated with a higher incidence of haematoma formation $(\chi=0.626)$. Nine of the 11 haematomas occurred when the drain was removed at 48 to 72 hours, and five of these nine drains had been non-functional for the 24 hours preceding removal. Thus it is reasonable to assume that earlier drain removal would not have exaggerated haematoma development. Furthermore, it is possible that tube blockage could have caused arrest of drainage in the five cases referred to, and earlier drain removal, with the possibility of free drainage, might have reduced the haematoma.

The positive cultures obtained in seven cases from the deep wound aspirate were identical to skin organisms cultured from that patient. The identical analytical profile indices and antibiotic sensitivities of the staphylococci cultured do not conclusively prove the origin of the organisms, but make the patients' skin the most likely source. Of the positive cultures obtained, five were from drains removed at $\mathbf{4 8}$ hours and two from drains removed at 72 hours; in two of these seven cases clinical wound sepsis followed although no organism could be isolated from the wound swabs. In four of the seven positive deep cultures the same organism was isolated from the surface of the $4 \mathrm{~cm}$ of suction drain which were in contact with the superficial tissues deep to the skin. Although skin contamination of the drain surface during 
removal cannot be excluded it seems unlikely as this was not observed in any of the other 113 drains removed which had sterile deep cultures.

This study re-affirms the risk of ingress of skin micro-organisms into the wound either by way of the drain or drain track with an increased rate of wound sepsis. This is seen, however, only if the drainage tube remains in situ more than 24 hours $(\chi=0.825$, $0.10<p>0.05$ ). By 24 hours postoperatively, the majority of wound aspiration has occurred and the risk of haematoma formation is not reduced by the continued presence of the drain. We therefore conclude that deep suction drains should be removed at the earliest time when aspiration has been completed, and certainly by 24 hours postoperatively following total hip replacement. Failure to do so may subject the patient to an increased risk of deep sepsis.

His co-authors report with deep regret the sudden death of Chris Simmons while on duty on January $21,1988$.

No benefits in any form have been received or will be received from a commercial party related directly or indirectly to the subject of this article.

\section{REFERENCES}

Browett JP, Gibbs AN, Copeland SA, Deliss LJ. The use of suction drainage in the operation of meniscectomy. J Bone Joint Surg [Br] 1978;60-B:516-9.

Casey BH. Bacterial spread in polyethylene tubing: a possible source of surgical wound contamination. Med J Aust 1971;1:718-9.

Cerise EJ, Plerce WA, Diamond DL. Abdominal drains: their role as a source of infection following splenectomy. Ann Surg $1970 ; 171: 764-9$.

Cruse PJ, Foord R. A five-year prospective study of 23,649 surgical wounds. Arch Surg 1973;107:206-10.

Magee C, Rodeheaver GT, Golden GT, Fox J, Edgerton MT, Edlich RF. Potentiation of wound infection by surgical drains. Am J Surg 1976;131:547-9.

Morris AM. A controlled trial of closed wound suction drainage in mastectomy. Br J Surg 1973;60:357-9.

Nora PF, Vanecko RM, Bransfield JJ. Prophylactic abdominal drains. Arch Surg 1972;105:173-5.

Raves JJ, Slinkin M, Diamond DL. A bacteriologic study comparing closed suction and simple conduit drainage. Am $J$ Surg 1984;148:618-20.

Reilly TJ, Grandisar IA, Jr, Parkan W, Reilly M. The use of postoperative suction drainage in total knee arthroplasty. Clin Orthop 1986;208:238-42.

Waugh TR, Stinchfield FE. Suction drainage of orthopaedic wounds. $J$ Bone Joint Surg [Am] 1961;43-A :939-46. 